\title{
MENINGKATKAN HASIL BELAJAR DAN MINAT BACA PADA MUPEL IPA MENGGUNAKAN METODE SURVEY,QUESTION, READ, RECITE PADA KELAS 5 SD
}

\author{
Sri Ambarwati ${ }^{1}$, Suroso $^{2}$, Yustinus ${ }^{3}$ \\ 1Pendidikan Guru Sekolah Dasar, Universitas Kristen Satya Wacana,292014013@student.uksw.edu \\ 2Pendidikan Guru Sekolah Dasar, Uiversitas Kristen Satya Wacana, suroso.sltg@gmail.com \\ 3Pendidikan Guru Sekolah Dasar, Universitas Kristen Satya Wacana, ytinus@staff.uksw.edu)
}

\begin{tabular}{|c|c|}
\hline INFO ARTIKEL & ABSTRAK \\
\hline $\begin{array}{l}\text { RiwayatArtikel: } \\
\text { Diterima: } 24-03-2018 \\
\text { Disetujui: } 06-04-2018\end{array}$ & $\begin{array}{l}\text { Abstrak: Penelitian ini bertujuan untuk meningkatkan hasil belajar dan minat baca siswa } \\
\text { kelas } 5 \text { SDN Salatiga } 9 \text {. Instrumen yang digunakan untuk menggumpulkan data pada } \\
\text { penelitian ini adalah angket untuk mengetahui minat baca siswa dengan indikator } \\
\text { berdasarkan dari metode SQ3R. Dan instrumen yang digunakan untuk mengetahui hasil } \\
\text { belajar siswa adalah soal evaluasi sebanyak } 20 \text { butir soal. Hasil belajar pada pra siklus atau } \\
\text { kondisi awal prosentasi hasil belajar siswa yang mencapai KKM hanya } 61,69 \% \text {, meningkat }\end{array}$ \\
\hline Kata Kunci: & $\begin{array}{l}\text { pada siklus } \mid 67,91 \% \text {, dan meningkat kembali pada siklus } \| \text { 78,5\%. Hasil minat baca pada pra } \\
\text { siklus } 69,38 \text {, meningkat pada siklus I } 70,00 \% \text {, dan meningkat pada siklus II } 89,75 \% \text {. }\end{array}$ \\
\hline $\begin{array}{l}\text { Metode SQ3R } \\
\text { Minat Baca } \\
\text { Hasil belajar } \\
\text { IPA }\end{array}$ & $\begin{array}{l}\text { Abstract: This study aims to improve learning outcomes and interest in reading grade } 5 \\
\text { SDN Salatiga 9. Instruments used to collect data in this study is a questionnaire to determine } \\
\text { the interest of reading students with indicators based on the SQ3R method. And the } \\
\text { instrument used to find out student learning outcomes is a matter of evaluation as much as } \\
20 \text { items. Learning outcomes in the pre cycle or initial condition of the percentage of student } \\
\text { learning outcomes that reached the KKM only } 61.69 \% \text {, increased in cycle / 67.91\%, and } \\
\text { increased again in cycle /I } 78.5 \% \text {. The result of reading interest in pre cycle } 69,38 \text {, increased } \\
\text { at cycle / } 70,00 \% \text {, and increase at cycle } / / 89,75 \% \text {. }\end{array}$ \\
\hline
\end{tabular}
cycle I 70,00\%, and increase at cycle // 89,75\%

\section{A. LATAR BELAKANG}

Permendikbud RI nomer 57 tahun 2014 tentang kurikulum 2013 sekolah Dasar/Madrasah Ibtidiyah menyatakan bahwa pelaksanaan pembelajaran pada Sekolah Dasar/Madrasah dilakukan dengan pendekatan tematik-terpadu. Pembelajaran tematikterpadu merupakan muatan pembelajaran dalam mata pelajaran Sekolah Dasar/Madrasah Ibtidaiyah yang diorganisasikan dalam tema-tema. Melalui penerapan pembelajaran tematik terpadu di sekolah dasar/madrasah ibtidaiyah menunjukkan bahwa penyampaian materi pembelajaran berbeda dengan kurikulum sebelumnya yaitu Kurikulum Satuan Tingkat Pendidikan (KTSP) yang dalam penyampaiannya mata pelajaran secara terpisah.

Oemar Hamalik (2017 : 158) menjelaskan bahwa kurikulum terintegrasi atau terpadu (Integreted Curriculum), batas-batas diantara semua mata pelajaran sudah tidak terlibat sama sekali. Semua mata pelajaran sudah dirumuskan dalam bentuk masalah satu unit. Pembelajran tematik terpadu dalam kurikulum 2013 perpaduan antara mata pelajaran dirumuskan dalam bentuk tema yang terdiri dari beberapa sub tema dan dalam satu subtema terdiri 6 pembelajaran.
Salah satu tema pembelajaran dalam kurikulum 2013 untuk kelas V SD adalah Lingkungan Sahabat Kita yang terdiri dari 4 subtema. Subtema yang kedua yaitu perubahan lingkungan tersebut terdiri dari 3 mata pelajaran yaitu, Bahasa Indonesia, IPA, dan SBdP yang disampaikan oleh guru secara tematik terpadu sehingga batas-batas diantara mata pelajaran tidak terlihat sama sekali oleh siswa. Guru perlu memiliki strategi mengajar yang baik agar pembelajaran tematik terpadu dapat terlaksana dan tujuan pembelajaran dapat tercapai.

Dalam proses pembelajaran tematik guru harus mengerti bagaimana memberikan rangsangan sehingga siswa menyukai pelajaran tematik dan lebih memahami materi yang diberikan oleh guru, serta mampu mengatasi masalah-masalah adanya sekelompok siswa yang menunjukkan kegagalan dengan berusaha mengetahui dan mengatasi penyebab yang menghambat proses pembelajaran. Salah satu untuk menarik dan meningkatkan daya ingat siswa dalam pembelajaran tematik adalah dengan salah satu metode SQ3R. Metode membaca SQ3R adalah metode pembelajaran yang sangat diperlukan agar siswa mengusai materi mupel IPA dengan baik dan mampu meningkatkan minat baca dan hasil belajar siswa dalam materi pelajaran tersebut. 
Hasil observasi awal yang dilakukan terhadap proses pembelajaran tematik di kelas V SDN Salatiga o9 diperoleh informasi bahwa selama proses pembelajaran, guru belum memberdayakan seluruh potensi dirinya dalam pembelajaran sehingga sebagian besar siswa belum mempuyai minat baca dalam belajar akibatnya mereka belum mampu mencapai kopetensi individual yang diperlukan untuk mengikuti pembelajaran selanjutnya. Siswa baru mampu menghafal fakta, kosep, prinsip, hukum, teori, dan gagasan inovatif lainnya pada tingkat ingatandan penggunaan media pembelajaran juga masih kurang, sehingga hasil belajar kurang maksimal. Dengan menerapkan metode SQ3R dalam menyampaikan pembelajaran tematik diharapkan siswa memiliki pengetahuan, pemahaman belajar lebih bermakna, mampu menghubungkan materi yang dipelajari dengan kehidupan nyata dan menumbuhkan kreatifitas sehingga meningkatkan minat baca dan hasil belajar siswa.

Penelitian yang dilakukan oleh Nurrina Dyahpuspita (2015) menunjukan bahwa kemampuan membaca dengan metode SQ3R lebih tinggi, hal ini dibuktikan dari hasil t-testdengan taraf signifikan 5\% (derajat kepercayaan 95\%) diperoleh t hitung $(2,646)>$ $\mathrm{t}$ tabel $(2,021)$. Nilai $\mathrm{t}$ hitung $>\mathrm{t}$ table menunjukkan kemampuan membaca pemahaman kedua kelompok berbeda signifikan.Oleh karena itu penggunaan model SQ3R lebih berhasil dalam meningkat niat baca dan daya ingat siswa dalam memahami materi.

Dari kedua penilitian di atas dapat disimpulkan bahwa pembelajaran SQ3R dapat meningkat hasil belajar dan juga minat baca siswa dalam menguasai materi. Keunggulannya adalah penerapan pada siswa mudah karena hanya mengandalkan membaca pemahaman. Pemahaman siswa akan terbentuk jika membaca berulang-ulang. perbedaan pemaparan dua penilitian tersebut adalah penerapan metode SQ3R yang digunakan untuk mengetahui siswa dalam mengusai materi khususnya dalam mupel IPA. Maka dari itu penulis ingin melakukan penelitian dengan menerapkan metode SQ3R untuk meningkatkan hasil belajar dan minat baca siswa kelas V pada mupel IPA.

\section{B. KAJIAN PUSTAKA}

\section{Pengertian Pembelajaran Tematik Terpadu}

Pembelajaran tematik terpadu merupakan pembelajaran yang menggunakan tema pada proses pembelajaran. Kemendikbud (2013:7) pembelajaran tematik terpadu adalah pembelajaran dengan memadukan beberapa mata pelajaran melalui penggunaan tema, dimana peserta didik tidak mempelajari materi pelajaran secara terpisah, semua mata pelajaran yang ada di sekolah dasar sudah melebur menjadi satu kegiatan pembelajaran yang diikat dengan tema.
Mulyasa (2013:170) pembelajaran tematik terpadu adalah pembelajaran yang diterapkan pada tingkatan pendidikan dasar yang menyuguhkan proses belajar berdasarkan tema untuk kemudian dikombinasikan dengan mata pelajaran lain. Triatno (2010: 9) bahwa pembelajaran terpadu harus menggunakan tema yang relevan dan berkaitan. Sedangkan menurut Prastowo (2013: 223) pembelajaran tematik terpadu merupakan pendekatan pembelajaran yang mengintegrasikan berbagai kompetensi dari berbagai mata pelajaran ke dalam berbagai tema.

Berdasarkan pendapat dari para ahli diatas, dapat disimpulkan bahwa pembelajaran tematik terpadu merupakan pembelajaran yang memadukan beberapa mata pelajaran dalam satu tema tertentu, pembelajaran tematik merupakan pembelajaran terpadu yang menekankan keterlibatan siswa dalam pembelajaran.

\section{Minat Baca}

Setiap orang mempunyai rasa ketertarikan pada sesuatu. Rasa ketertarikan tersebut dapat terjadi karena adanya objek yang menimbulkan rasa tertarik, dan rasa ingin tahu yng dimiliki oleh orang tersebut. Ketertarikan pada sebuah objek, dapat membuat orang menjadi antusias dan senang untuk mengetahui apa sesungguhnya objek tersebut. Demikian juga dengan minat membaca, minat baca adalah rasa tertarik seseorang pada buku bacaan karena isi yang terkandung pada bacaan tersebut. Bastian (2007:4.27) menyatakan, bahwa minat baca bukanlah sesuatu yang dimiliki oleh seseorang begitu saja, melainkan merupakan sesuatu yang dapat dikembangkan.

Menurut Herman Wahadaniah (Yunita Ratnasari, 2011: 16) minat baca adalah suatu perhatian yang kuat dan mendalam disertai dengan perasaan senang terhadap kegiatan membaca sehingga dapat mengarahkan seseorang untuk membaca dengan kemauannya sendiri atau dorongan dari luar. Minat membaca juga merupakan perasaan senang seseorang terhadap bacaan karena adanya pemikiran bahwa dengan membaca itu dapat diperoleh kemanfaatan bagi dirinya.

Dari pendapat di atas dapat disimpulkan bahwa minat baca terkandung unsur, perhatian, kemauan, dorongan dan rasa senang membaca.perhatian bisa didapat dari perhatiannya terhadap kegiatan membaca, mempunyai kemauan yang tinggi untuk membaca, dorongan dan rasa senag yang timbul dari dalam diri maupun dari pengaruh orangorang lain. Semua itu merupakan aktivitas yang dilakukan dengan penuh ketekunan dan cenderung menatap.

Dawson dan Bamman dalam (Rahman, 1985: 6-8) mengemukakan prinsip-prinsip yang mempengaruhi minat baca adalah sebagai berikut:

a. Seseorang atau siswa dapat menemukan kebutuhan dasarnya lewat bahan-bahan bacaan jika topik, isi, pokok-persoalan, 
tingkat kesulitan, dan cara penyajiannya sesuai dengan kenyataan individu, merupakan salah satu faktor yang berpengaruh terhadap minat bacanya.

b. Kegiatan dan kebiasaan membaca dianggap berhasil atau bermanfaat jika siswa memperoleh kepuasan dan dapat memenuhi kebutuhan-kebutuhan dasarnya, yaitu rasa nyaman, status, kedudukan tertentu, kepuasan efektif dan kebebasan yang sesuai dengan fakta serta tingkat perkembangannya. Jika kegiatan membaca dianggap menguntungkan seseorang, maka membaca merupakan sutu kegiatan yang dianggap sebagai salah satu kebutuhan hidup.

c. Adanya sarana buku bacaan dalam keluaraga adalah salah satu faktor pendorong terhadap pilihan bahan bacaan dan minat baca. Macam-macam bacaan yang memadai dalam keluarga akan sangat membantu anak dalam meningkatkan minat baca.

d. Sarana perpustakaan sekolah yang relatif lengkap dan sempurna serta kemudahan proses peminjamannya merupakan faktor besar yang mendorong minat baca siswa.

e. Program khusus kurikuler yang memberikan kesempatan siswa untuk membaca secara periodik di perpustakaan sekolah sangat mendorong perkembangan dan peningkatan mina baca siswa.

f. Teman-teman sekelas sebagai faktor eksternal yang dapat mendorong timbulnya minat baca siswa. pergaulan teman dalam sekolah menjadi salah satu faktor yang mempengaruhi pembentukan minat. Siswa yang berminat terhadap kegiatan membaca, akan lebih sering mengajak temannya ikut melakukan kegiatan membaca baik di dalam kelas ataupun perpustakaan sehingga memberikan pengaruh positif terhadap temannya.

g. Faktor guru yang berupa kemampuan mengelola kegiatan dan interaksi belajar mengajar, khususnya dalam program pengajaran membaca. Guru yang baik harus mengetahui karakteristik dan minat anak didiknya. Guru bisa menyajikan berupa bacaan yang lebih menarik dan bervariasi untuk mendorong minat baca siswa.

h. Faktor jenis kelamin juga menjadi salah satu yang mendorong pemilihan buku. Anak perempuan biasanya lebih suka untuk membaca novel, cerita drama maupun cerita prsahabatan, sedangkan anak laki-laki biasanya lebih suka cerita bertema kepahlawan.
Rahim (2011: 1) pengaruh minat baca di antaranya membuat seseorang memperoleh pengetahuan dan wawasan baru yang akan semakin meningkatkan pengetahuannya juga perpengaruh pada hasil belajar. Apabila siswa sudah memiliki minat baca yang tinggi maka hasil belajarnya juga akan meningkat, begitu juga sebaliknya jika siswa memiliki minat baca yang rendah maka hasil belajar juga menurun. Strategi yang digunakan agar minat baca dapat meningkatkan hasil belajar adalah 1) proses pembelajaran mengarahkan kepada peserta didik untuk rajin membaca terlebih membaca tentang materi pelajaran, 2) mengingatkan siswa untuk selalu membaca buku di perpustakaan,karena semakin banyak buku yang mereka baca akan lebih banyak pengetahuan yang mereka ketahui, 3) mencatat informasi penting tentang materi bacaan yang ada pada buku pelajaran,4) memberi tugas membaca tentang materi pelajaran yang terdapat dalam buku pelajaran atau pun buku lain yang berhubungan dengan materi pembelajaran.

\section{Hasil Belajar}

Hasil belajar merupakan bagian terpenting dalam pembelajaran Nana Sudjana (2009: 3) mendefinisikan hasil belajar siswa pada hakikatnya adalah perubahan tingkah laku sebagai hasil belajar dalam pengertian yang lebih luas mencakup bidang kognitif, afektif, dan psikomotorik. Dimyati dan Mudjiono dan Mudjiono (2006: 3-4) juga menyebutkan hasil belajar merupakan hasil dari suatu interaksi tindak belajar dan tindak mengajar. Dari sisi guru, tindak mengajar diakhiri dengan proses evaluasi hasil belajar. Dari sisi siswa, hasil belajar merupakan berakhirnya pengajaran dari puncak proses belajar.

Menurut Bred dan Gredler dalam Winataputra, (2008) hasil Belajar adalah hasil dari proses yang dilakukan manusia untuk mendapatkan aneka ragam Competencies, Skill, And Attitudes. Kemampuan (Competencies), Ketrampilan (Skill), dan Sikap (Attidude) tersebut diperoleh secara bertahap mulai dari bayi sampai masa tua sebagai rangkaian belajar sepanjang hayat. Rangkaian proses belajar itu dilakukan dalam bentuk keterlibatannya dalam pendidikan informal, formal dan nonformal. Kemampuan belajar inilah yang membedakan manusia dengan makhluk lainnya.

Berdasarkan penjelasan beberapa tokoh di atas, dapat disimpulkan bahwa hasil belajar adalah kemampuan-kemampuan yang dimiliki siswa setelah menerima pengalaman belajarnya. Kemampuankemampuan tersebut mencakup aspek kognitif, afektif, dan psikomotorik. Hasil belajar dapat dilihat melalui kegiatan evaluasi yang bertujuan untuk mendapatkan data pembuktian yang akan menunjukkan tingkat kemampuan siswa dalam mencapai tujuan pembelajaran, tingkat pemahaman, sikap dan ketrampilan siswa yang diperoleh dari proses belajar. 
Hasil belajar diukur dengan dengan pemberian skor atau nilai.

\section{Pembelajaran IPA}

Ilmu pengetahuan alam atau sains (science) diambil dari kata latin Scientia yang arti harfiahnya adalah pengetahuan, seperti yang telah dirumuskan Sund dan Trowbribge bahwa sains adalah kumpulan pengetahuan dan proses. Sedangkan Kuslan Stone menyebutkan bahwa Sains adalah kumpulan pengetahuan dan cara-cara untuk mendapatkan dan mempergunakan pengetahuan itu. Sains merupakan produk dan proses yang tidak dapat dipisahkan. "Read Science is both and process, inseparably Joint” Agus. S dalam Wikipedia (2013).

(Puskur, 2009) menyatakan bahwa Ilmu Pengetahuan Alam (IPA) berkaitan dengan cara mencari tahu tentang alam secara sistematis, sehingga IPA bukan hanya penguasaan kumpulan pengetahuan yang berupa fakta-fakta, konsep-konsep, atau prinsipprinsip saja tetapi juga merupakan suatu proses penemuan. Menurut H.W Flowler dalam (Trianto, 2012) IPA adalah pengetahuan yang sudah sistematis, tersusun dan dirumuskan yang berdasarkan pada pengamatan ataupun dedukasi, serta berkaitan dengan gejala-gejala kebendaan.

Berdasarkan pengertian di atas, dapat disampulkan bahwa IPA merupakan kumpulan teori sistematis yang meliputi penguasaan konsep, fakta, prinsip yang menuntut sikap ilmiah dan hasilnya terwujud dalam produk ilmiah.

Tujuan dari pembelajaran IPA adalah:

a. Pembelajaran IPA pada kurikulum 2013 disusun dengan memperhatikan ketrampilan proses IPA yang meliputi ketrampilan proses lanjut. Ketrampilan proses dasar meliputi mengukur, observasi, inferensi, prediksi, klasifikasi, dan komunikasi.

b. Kegiatan pembelajaran IPA dikembangkan dengan pendakatan scientific dan ketrampilan proses sains lainnya

c. Pembelajaran IPA dikembangkan dengan berbasis Scientific yang lebih menekankan proses ilmiah

\section{Metode Pembelajaran SQ3R}

Metode SQ3R dikembangkan oleh Francis P. Robinson dalam Miftahul Huda (2013), seorang guru besar psikologi dari Ohio State Unifersity sejak tahun 1941. SQ3R merupakan metode yang sangat baik secara intensif dan rasional. Metode ini lebih tepat diperlukan untuk keperluan studi. Karena itu metode ini dirancang menurut jenjang yang memungkinkan siswa untuk belajar sistematis, dan efisien.

SQ3R merupakan metode yang membantu siswa berpikir tentang teks yang sedang mereka baca. Sering kali dikatagorikan sebagai strategi belajar, SQ3R membantu siswa "mendapatkan sesuatu" ketiaka pertama kali mereka membaca teks. Bagi guru, SQ3R membantu mereka dalam membimbing siswa bagaimana membaca dan berpikir layaknya para pembaca efektif (Miftahul Huda: 244).

Sedangkan menurut (Herdian, 2009: 1) Metode pembelajaran SQ3R adalah strategi membaca yang dapat mengembangkan metakognitif siswa, yaitu dengan menugaskan siswa untuk membaca bahan belajar secara seksama cermat. Jadi metode membaca SQ3R adalah cara yang digunakan untuk membaca dengan tahapan, Survey atau meninjau, Question atau bertanya, Read atau membaca, Recite atau menuturkan, Review atau mengulang.

Jadi metode pembelajaran SQ3R adalah strategi pemahaman membaca dan mampu mengusai materi terutama materi pelajaran berupa bacaan.

Menurut (Al-Hafizh, 2012) kelebihan metode SQ3R, siswa dapat:

a. Tebiasa berfikir terhadap bahan bacaan sehingga siswa menjadi lebih aktif dan terlatih untuk bisa membuat pertanyaan.

b. Berusaha untuk memikirkan jawaban-jawaban dari pertanyaan yang mendalami isi bacaan atau teks tersebut.

c. Saling bertukar pendapat dalam memahami konsep materi yang disajikan dalam uraian teks.

Dalam penerapan suatu metode pembelajaran pasti tidak akan lepas dari kekurangan. Kekurangan metode pembelajaran SQ3R menurut Fitria (2011) antara lain:

a. Materi yang disajikan hanya berupa materi bacaan.

b. Siswa sulit dikondisikan (ramai) saat berdiskusi dengan teman sebangkunya dalam mempelajari teks materi pelajaran

Metode ini mencakup lima langkah adalah sebagai berikut ini (Robinson,1946) :

a. Survey, siswa meriview teks atau bacaan untuk memperoleh makna awal dari judul, tulisantulisan yang dibold, dan bagan-bagan.

b. Question, siswa memulai membuat pertanyaanpertanyaan tentang bacaan mereka dari hasil survei pertama.

c. Read, Ketika siswa membaca, mereka harus mencari jawaban-jawaban atas petanyaanpertanyaan yang telah mereka formulasikan saat memperiview teks itu sebelumnya. Pertanyaan-pertanyaan ini, yamg didasarkan pada struktur teks, akan membantu kosentrasi dan fokus siswa pada bacaan.

d. Recite, Ketika siswa tengah melewati teks itu, mereka seharusnya membacakan dan mengulangi jawaban-jawaban atas pernyataan mereka dan membuat catatan mengenai jawaban mereka untuk pelajaran selanjutnya.

e. Review, Selesai membaca, siswa seharusnya meriview teks itu untuk menjawab pertanyaan- 
pertanyaan selanjutnya dengan mengingat kembali petanyaan-pertanyaan yang telah meraka jawab sebelumnya.

\section{Kajian Hasil Penelitian yang Relevan}

Metode SQ3R telah diteliti oleh beberapa peneliti terdahulu antara lain adalah, penelitian yang berjudul "Upaya meningkatkan hasil belajar mata pelajaran IPA kelas V SDN Soborejo Pringsurat dengan menggunkan metode SQ3R" oleh Eddy Aprilia (2013) dalam hal ini metode SQ3R dapat meningkatkan minat baca dan hasil belajar. Dengan perolehan persentase hasil belajar $41,7 \%$ meningkat pada siklus I yakni $66,3 \%$. Pada akhir siklus II juga terjadi peningkatan hasil belajar siswa menjadi $91,7 \%$.

Sedangkan penelitian yang berjudul Penerapan Metode SQ3R Untuk Meningkatkan Ketrampilan Membaca Pemahaman Siswa Kelas V SD Negeri Gajahmungkur 02 Semarang oleh Hasan Triyakti (2012). Hasil peneletian menunjukan bahwa ketrampilan guru dalam mengelola pembelajaran membaca pemahaman, aktivitas siswa dalam pembelajaran membaca pemahaman, dan ketrampilan membaca pemahaman siswa yang ditunjukkan dari ketuntasan belajar siswa mengalami peningkatan yang signifikan pada masing-masing pertemuan pada tiap siklusnya.. Ini menunjukan bahwa indikator keberhasilan yang ditetapkan sebesar $75 \%$ telah terpenuhi sehingga penelitian ini dinyatakan berhasil

Penelitian yang berjudul Penerapan pembelajaran membaca cepat melalui metode SQ3R untuk meningkatkan prestasi belajar siswa dalam bidang studi bahasa Indonesia dikelas IV SDN Jatitengah 02 Kecamatan Selopuro Kabupaten Blitar Burhanudi Aulia Prista (2012), hasil prestasi belajar siswa dalam bentuk pengetahuan kebahasaan meningkat dari 69,64\% pada pra tindakan meningkat menjadi $73,92 \%$ pada siklus I dan meningkat lagi menjadi $76,43 \%$ pada siklus II, hasil prestasi belajar dalam bentuk informasi verbal yaitu jumlah penguasaan kata dari batas minimla yang ditentukan yaitu $150 \mathrm{kpm}$ (kata per menit) hanya 6siswa yang mampu memenuhinya pada tahap pra tindakan. Jumlah siswa yang mampu memenuhi kriteria minimal $150 \mathrm{kpm}$ meningkat menjadi 8 siswa pada siklus I dan meningkat lagi menjadi 10 siswa pada siklus II, dengan demikian kriteria $75 \%$ telah terpenuhi karena 10 siswa dari total 14 siswa telah memenuhi batas minimal $150 \mathrm{kpm}$. Hasil prestasi belajar siswa dalam bentuk kemahiran intelektual yaitu pemahaman isi bacaan, pada tahapan pra tindakan hanya hanyai mencapai 56,92\%, hal ini meningkat menjadi 70,85\% pada siklus I, sedangkan pada siklus II meningkat menjadi $76,57 \%$. Kelebihan metode membaca tersebut adalah jika diterapkan pada muatan pelajaran Bahasa Indonesia dapat meningkatkan pengetahuan kebahasaan, dan pemahaman isi bacaan. Kelemahannya adalah kurang baik diterapkan untuk anak yang memiliki keceptan membaca rendah. Solusi dari kelemahan tersebut adalah perlu pelatihan dalam kecepatan membaca sebelum diterpkan metode SQ3R.

Dari berbagai penelitian di atas dapat disimpulkan bahwa metode pembelajran SQ3R dapat meningkakan hasil belajar siswa. Kelebihannya adalah penerapan pada siswa mudah karena hanya mengandalkan membaca pemahaman. Pemhaman siswa akan terbentuk ketika mereka membaca berulang-ulang. Sedangkan kelemahannya adalah sulit diterapkan pada anak yang mempunyai kemampuan membaca rendah.

\section{Kerangka Berfikir}

Berdasarkan observasi yang telah dilakukan dan kajian pustaka penelitian yang relevan minat baca merupakan hal yang sangat menunjang untuk pembelajaran yang akan dilaksanakan. Minat membaca sebagai acuan utama untuk belajar agar bisa memahami semua muatan pembelajaran. Mengandalkan membaca berpengaruh juga terhadap hasil belajar siswa. Model pembelajaran SQ3R strategi membaca yang dapat mengembangkan metakognitif siswa, yaitu dengan menugaskan siswa untuk membaca bahan belajar secara seksama dan cermat. Model tersebut diharapkan dapat meningkatkan minat baca dan hasil belajar pada muatan pembelajaran IPA. Apabila minat baca siswa meningkat dalam memahami materi, maka akan meningkatkan hasil belajar siswa. oleh karena itu diperlukan suatu pembelajaran yang melibatkan anak agar dapat lebih tertarik untuk membaca agar mereka dapat meningkatkan hasil belajar. Salah satu metode yang digunakan disini adalah metode SQ3R karena dengan metode ini dapat digunakan untuk meningkatkan minat baca dan hasil belajar anak.

\section{Hipotesis Penelitian}

Berdasarkan kerangka berfikir dan penelitian yang relevan dapat disimpulkan hipotesis tindakan adalah penerapan metode pembelajaran tipe $S Q 3 R$ akan meningkatkan hasil belajar dan minat baca pada muatan pelajaran IPA menggunakkan metode SQ3R pada kelas V SDN Salatiga 9 tahun pelajaran 2017/2018.

\section{METODE PENELITIAN}

Penelitian ini berbentuk Penelitian Tindakan Kelas (Classroom Action Research). Hopkins ( dala Rochiati Wiriaatmadja, 2007: 11) menyatakan bahwa penelitian tindakan kelas adalah sebuah penelitian yang mengkombinasikan prosedur penelitian dengan tingkat substansif, atau suatu usaha seseorang untuk memahami apa yang sedang terjadi dan terlibat dalam sebuah proses perbaikan dan perubahan. Penelitian ini menggunakan 3 teknik pengumpulan data yakni, observasi, angket, tes.

Subjek dalam penelitian ini adalah siswa kelas V SDN Salatiga 09, Kecamatan Sidorejo, Kota Salatiga. 
Jumlah siswa kelas ini terdiri dari 21 laki-laki dan 22 perempuan. Alasan penululis memilih kelas V SDN Salatiga o9 sebagai subjek penelitian adalah berdasarkan hasil observasi yang telah dilakukan peneliti dan ditemukan beberapa masalah. Permasalahan yang terdapat di kelas tersebut adalah minat baca dan hasil belajar siswa yang masih tergolong rendah, karena pembelajaran yang diterapkan masih menggunakan metode konvensional sehingga pembalajaran terkesan monoton, hal tersebut berdampak pada hasil belajar dan minat baca siswa. Oleh sebab itu, peneliti berinisiatif untuk menerapakan metode pembelajaran yang dapat meningkatkan minat baca dan hasil belajar siswa. salah satu dengan menggunakan metode SQ3R

Variabel dalam penelitian ini terdiri dari dua variabel, yakni variabel bebas (X) dan variabel terikat (Y). Uraian kedua variabel tersebut dapat dibaca seperti dibawah ini:

\section{Variabel Bebas (X)}

Variabel bebas ini merupakan variabel yang mempengaruhi atau yang menjadi sebab perubahan atau timbulnya variabel terikat. Dalam penilitian ini variabel bebas $(\mathrm{X})$ yaitu metode pembelajaran SQ3R.

2. Variabel Terikat $(\mathrm{Y})$

Variabel ini merupakan variabel terpengaruhi atau yang menjadi akibat variabell bebas (Variabel X). Dalam penelitian ini variabel terikat (variabel Y) minat baca dan hasil belajar IPA siswa kelas V SDN Salatiga 09, Kecamatan Sidorejo, Kota Salatiga.

\section{HASIL PENELITIAN DAN PEMBAHASAN \\ 1. Deskripsi Kondisi Awal}

Penelitian ini dilaksanakan di SDN Salatiga o9, Kecamatan Sidorejo, Kota Salatiga. Kelas yang digunakan untuk penelitian ini adalah kelas 5 yng berjumlah 43 siswa yang terdiri dari 21siswa laki-laki dan 22 siswa perempuan. Penelitian ini dilakukan untuk mengetahui peningkatan minat baca dan hasil belajar siswa menggunakan metode SQ3R pada semester II tahun ajaran 2017/2018. Penelitian ini dilaksanakan pada bulan maret. Sebelum siklus 1 dan siklus 2 dilaksanakan, peneliti terlebih dahulu melakukan observasi pada guru kelas saat melakukan pembelajaran IPA, setelah observasi selesai peneliti meminta hasil nilai siswa pngumpulan data ini bertujuan untuk mengetahui pandangan awal hasil belajar selama ini. Setelah mendapatkan data nilai siswa, kemudian dilanjutkan dengan menggumpulkan data minat baca siswa.

\section{a. Hasil Belajar Siswa}

Sebelum pelaksanaan tindakan penelitian dilaksanakan. Berikut adalah tabel hasil belajar IPA sebelum dilaksanakan tindakan penelitian:
TABEL 4

HASIL BELAJAR IPA PRA SIKLUS

\begin{tabular}{|c|c|c|c|}
\hline No & Nilai & $\begin{array}{c}\text { Jumlah } \\
\text { siswa }\end{array}$ & $\begin{array}{c}\text { Presentasi } \\
\text { (\%) }\end{array}$ \\
\hline 1 & $45-55$ & 12 & 27,91 \\
\hline 2 & $56-65$ & 14 & 32,76 \\
\hline 3 & $66-75$ & 9 & 22,94 \\
\hline 4 & $76-85$ & 3 & 6,98 \\
\hline 5 & $86-100$ & 4 & 9,41 \\
\hline \multicolumn{2}{|c|}{ Jumlah } & 43 & 100 \\
\hline Rata-rata hasil belajar & \multicolumn{3}{|c|}{61,69} \\
\hline \multicolumn{2}{|c|}{ Skor tertinggi } & 45 \\
\hline \multicolumn{2}{|c|}{ Skor terendah } & \multicolumn{3}{|c|}{} \\
\hline
\end{tabular}

Berdasarkan tabel 1 dapat dilihat bahwa siswa yang mendapatkan nilai dengan rentang $45-55$ sebanyak 12 siswa ( 27,91\%), siswa yang mendapatkan nilai pada rentang 56 - 65 sebanyak 14 siswa ( $32,76 \%$ ), siswa yang mendapatkan nilai pada rentang $66-75$ sebanyak 9 siswa (22,94\%), siswa yang mendapatkan nilai pada rentang $76-85$ sebanyak 3 siswa $(9,41 \%)$, siswa yang mendapatkan nilai pada rentang $86-100$ sebanyak 3 siswa (12\%). Nilai rata - rat siswa pada kondisi awal sebelum dilakukan penelitian tindakan kelas yaitu 61,69 Nilai terendah pada kondisi awal adalah 45 dan nilai tertinggi adalah 91.

\section{b. Minat Baca Siswa}

Untuk mendapatkan data minat baca siswa terhadap mauatan pelajaran IPA, telah disediakan angket yang disiapkan sebelumnya.

TABEL 2

SKOR ANGKA MINAT BACA IPA PRA SIKLUS

\begin{tabular}{|c|c|c|c|c|}
\hline No & Interval & Kategori & Frekuensi & $\begin{array}{c}\text { Presentasi } \\
\text { (\%) }\end{array}$ \\
\hline 1 & $21-38$ & $\begin{array}{c}\text { Sangat } \\
\text { Kurang }\end{array}$ & 3 & 6,70 \\
\hline 2 & $39-56$ & Kurang & 10 & 23,30 \\
\hline 3 & $57-74$ & Cukup & 8 & 18,64 \\
\hline 4 & $75-91$ & Baik & 14 & 32,72 \\
\hline 5 & $86-100$ & $\begin{array}{c}\text { Sangat } \\
\text { Baik }\end{array}$ & 4 & 9,41 \\
\hline \multicolumn{5}{|c|}{ Jumlah } \\
\hline Rata-rata hasil angket minat \\
baca
\end{tabular}

Dari data tabel 2 dapat dilihat bahwa siswa yang masuk kategori sangat kurang dari 3 siswa atau 6,70\%, kategori kurang 10 siswa atau 23,30\%, kategori cukup 8 siswa atau $18,64 \%$, kategori baik 14 siswa atau $32,72 \%$, dan kategori sangat baik 8 siswa atau 18,64\%. Rata-rata hasil angket siswa 69,38\% dalam kategori cukup.

\section{Deskripsi Pelaksanaan Tindakkan Siklus I}

\section{a. Tahap Perencanaan}

Setelah dilakukan observasi, peneliti melakukan diskusi dengan guru kelas $\mathrm{V}$ mengenai materi pembelajaran dan alat penunjang yang diperlakukan. Sebelum guru kelas V mengajar 
peneliti menyiapkan segala sesuatunya untuk menunjang proses pembelajaran. Yang perlu dipersiapkan diantaranya rencana pelaksanaan pembelajaran siklus 1. Lembar observasi guru saat mengajar menggunakan metode pembelajaran SQ3R, merencanakan kegiatan belajar-mengajar siklus I akan berlangsung sebanyak 2 kali pertemuan. Sebelum mengajar peneliti mempersiapkan hal-hal berikut:

1) Menyiapkan materi pelajaran yang akan disampaikan

2) Membuat kelompo heterogen.

3) Menyiapkan rencana pelaksanaan pembelajaran siklus 1 .

4) Menyiapkan lembar observasi guru dan siswa untuk mengetahui keberhasi penggunaan metode pembelajaran SQ3R.

5) Menyiapkan lembar angket minat baca untuk mengetahui minar baca siswa setelah pembelajaran.

6) Tes evaluasi

\section{b. Tahap Pelaksanaan}

Pertemuan pertama hari rabu, 14 Maret 2018. Pada pertemuan pertama terdapat tiga indikator pmbelajaran yang ingin disampaikan yaitu mengidentifikasi siklus air, menyebutkan manfaat air da menjelaskan evaporasi. Berikut ini langkah - langkah pembelajran dengan model SQ3R yang akan dilaksanakan pada pembelajran pertama siklus I.

\section{Pertemuan Pertama}

Pertemuan pertama hari rabu, 14 Maret 2018. Pada pertemuan pertama terdapat tiga indikator pmbelajaran yang ingin disampaikan yaitu mengidentifikasi siklus air, menyebutkan manfaat - manfaat air dan menjelaskan evaporasi. Berikut ini langkah - langkah pembelajran dengan model SQ3R yang akan dilaksanakan pada pembelajran pertama siklus I.

Pada kegiatan awal yang dilakukan oleh peneliti meliputi beberapa kegiatan yang telah didesain dalam rencana pelaksanaan pembelajaran (RPP) yaitu membuka pelajaran dengan mengucapkan salam, berdoa menurut agama dan kepercayaan masing - masing, mengabsen kehadiran siswa dan melakukan apersepsi. Sebelum masuk kedalam materi peneliti memberikan apersepsi kepada siswa dengan mengajak menyanyikan lagu "Garuda Pancasila" yang bertujuan untuk menumbuhkan rasa nasionalisme siswa. kemudian bersama siswa peneliti mengajak menyanyikan lagu" Tik - tik bunyi hujan". Peneliti menginfokan tema yamg akan di pelajari.
Pada awal pembelajaran peneliti memberikan stimulus ide, gagasan dan motivasi terhadap siswa dengan cara memberi pertanyaan kepada siswa. "Pernahkah Kalian melihat hujan?" "Darimanakah Hujan itu berasal?”. Siswa kemudian mulai menjawab petanyaan yang diberikan oleh peneliti. Kemudian siswa diminta untuk membeca dan mencermati teks tentang siklus air secara bergilir. Siswa diminta untuk menuliskan hal yang penting dari bacaan tersebut.kemudian siswa diminta membuat pertanyaan dari teks bacaan yang telah diberikan. Suasana pada proses ini siswa masih bingung dengan metode pembelajaran yang digunakan, masih ada siswa yang membuat kegaduhan. Penilaian pada proses ini adalah penilaian kognitf dan penilaian afektif siswa Setelah itu siswa diminta menukarkan pertanyaan yang sudah dibuat kepada teman. siswa diminta menjawab pertanyaan yang mereka bawa. Kemudian siswa membacakan pertanyaan dan jawaban di depan kelas secara bergiliran. Kemudian siswa diminta menuliskan kembali pertanyaan dan jawaban. kemudian peneliti memberikan pengutan terhadap jawaban siswa. kemudian peneliti memberikan bacaan tentang daur ulang air. Kemudian siswa diminta untuk menuliskan hal yang penting pada bacaan, serta membuat pertanyaan berdasarkan teks yang sudah diberikan. Kegiatan ini sebagi lembar kerja siswa. Setelah selesai siswa mengumpulkan pekerjaan mmasing - masing. Peneliti bersama siswa membuat kesimpulan tentang pelajaran hari ini.

Peneliti bersama siswa membuat penegasan atau kesimpulan tentang materi keliling dan luas bangun datar yang sudah dipelajari oleh siswa hari ini. Penelilti memberikan pesan kepada siswa untuk mempelajari lagi materi hari ini dan peneliti juga menginformasikan tentang materi selanjutnya yang akan dipelajari esok hari. Peneliti mengakhiri pembelajaran hari ini dengan mengucapkan salam.

\section{Pertemuan Kedua}

Pertemuan kedua hari kamis, 15 Maret 2018. Pada pertemuan kedua terdapat tiga indikator pembelajaran yang ingin disampaikan yaitu menjelaskan presipitasi, menjelaskan kondensasi, menjelaskan dampak positif dan negatif kehiatan manusia yang mempengaruhi siklus air. Berikut ini langkah - langkah pembelajran dengan model SQ3R yang akan dilaksanakan pada pembelajran pertama siklus I.

Kegiatan awal yang dilakukan oleh peneliti meliputi beberapa kegiatan yang telah didesain dalam rencana pelaksanaan pembelajaran (RPP) yaitu membuka pelajaran dengan mengucapkan salam, berdoa menurut agama dan kepercayaan masing - masing, mengabsen kehadiran siswa dan 
melakukan apersepsi. Sebelum masuk kedalam materi peneliti memberikan apersepsi kepada siswa dengan mengajak bernyanyi "Tik - tik bunyi hujan" Peneliti menginfokan tema yamg akan di pelajari.

Pada kegiatan inti, peneliti memberikan stimulus ide, gagasan dan motivasi terhadap siswa dengan cara memberi pertanyaan kepada siswa. "Pada saat terjadi hujan perkah kalian mengamati hal apa saja yang terjadi sebelum hujan?" “Apa penyebab terjadinya hujan?”. Siswa kemudian mulai menjawab petanyaan yang diberikan oleh peneliti. Peneliti menjelaskan secara singkat tentang proses terjadinya hujan Kemudian siswa diminta untuk membeca dan mencermati teks tentang siklus air hujan secara bergilir. Siswa diminta untuk menuliskan hal yang penting dari bacaan tersebut.kemudian siswa diminta membuat pertanyaan dari teks bacaan yang telah diberikan. Suasana pada proses ini siswa sudah mulai memahami dan nyaman dengan metode pembelajaran yang digunakan. penilaian pada proses ini adalah penilaian kognitf dan penilaian afektif siswa Setelah itu siswa diminta menukarkan pertanyaan yang sudah dibuat kepada teman. Siswa diminta menjawab pertanyaan yang mereka bawa. Kemudian siswa membacakan pertanyaan dan jawaban di depan kelas secara bergiliran. Kemudian siswa diminta menuliskan kembali pertanyaan dan jawaban. kemudian peneliti memberikan pengutan terhadap jawaban siswa. kemudian peneliti memberikan bacaan tentang daur ulang air. Kemudian siswa diminta untuk menuliskan hal yang penting pada bacaan, serta membuat pertanyaan berdasarkan teks yang sudah diberikan. Peneliti membagikan lembar evaluasi dan lembar angket. Peneliti bersama siswa membuat kesimpulan tentang pelajaran hari ini.

Peneliti bersama siswa membuat penegasan atau kesimpulan tentang materi keliling dan luas bangun datar yang sudah dipelajari oleh siswa hari ini. Penelilti memberikan pesan kepada siswa untuk mempelajari lagi materi hari ini dan peneliti juga menginformasikan tentang materi selanjutnya yang akan dipelajari esok hari. Peneliti mengakhiri pembelajaran hari ini dengan mengucapkan salam.

\section{c. Tahap Observasi Siklus I}

Observasi yang dilakukan juga meliputi observasi respon dengan cara mengamati minat siswa dengan menggunakan lembar angket minat siswa. Berdasarkan pengamtan respon minat siswa dari angket yang sudah diisi oleh siswa sendiri, siswa menunjukan respon minat yang positif dalam mengikuti pembelajaran matematika. Walaupun masih ada rasa jenuh siswa saat mengikuti proses pembelajaran yang berlangsung. Hasil observasi dapat dilihat pada tabel 4.3 , sedangkan respon minat baca siswa dapat dilihat pada tabel 3

TABEL 3

HASIL BELAJAR IPA SIKLUS I

\begin{tabular}{|c|c|c|c|}
\hline No & Nilai & $\begin{array}{c}\text { Jumlah } \\
\text { siswa }\end{array}$ & $\begin{array}{c}\text { Presentasi } \\
\text { (\%) }\end{array}$ \\
\hline 1 & $45-55$ & 9 & 20,93 \\
\hline 2 & $56-65$ & 9 & 20,93 \\
\hline 3 & $66-75$ & 10 & 23,26 \\
\hline 4 & $76-85$ & 8 & 18,61 \\
\hline 5 & $86-100$ & 7 & 16,27 \\
\hline Jumlah hasil & 43 & \multicolumn{3}{|c|}{67,91} \\
\hline $\begin{array}{l}\text { Rata-rata } \\
\text { belajar }\end{array}$ & \multicolumn{3}{|c|}{45} \\
\hline Skor tertinggi & \multicolumn{3}{|c|}{} \\
\hline Skor terendah & \multicolumn{3}{|c|}{} \\
\hline
\end{tabular}

Berdasarkan tabel 3 dapat dilihat bahwa siswa yang mendapatkan nilai dengan rentang 45 - 55 sebanyak 9 siswa ( 20,93\%), siswa yang mendapatkan nilai pada rentang 56 - 65 sebanyak 9 siswa ( 20,93\%), siswa yang mendapatkan nilai pada rentang 66 - 75 sebanyak 10 siswa (23,26\%), siswa yang mendapatkan nilai pada rentang 76 85 sebanyak 8 siswa $(18,61 \%)$, siswa yang mendapatkan nilai pada rentang $86-100$ sebanyak 7 siswa $(16,27 \%)$. Nilai rata - rat siswa pada kondisi awal sebelum dilakukan penelitian tindakan kelas yaitu 67,91 Nilai terendah pada kondisi awal adalah 45 dan nilai tertinggi adalah 95 .

Untuk mendapatkan data minat baca siswa terhadap mauatan pelajaran IPA, telah disediakan angket yang disiapkan sebelumnya.

TABEL 4

SKOR ANGKA MINAT BACA IPA PRA SIKLUS

\begin{tabular}{|c|c|c|c|c|}
\hline No & Interval & Kategori & Frekuensi & $\begin{array}{c}\text { Presentasi } \\
(\%)\end{array}$ \\
\hline 1 & $21-38$ & $\begin{array}{l}\text { Sangat } \\
\text { Kurang }\end{array}$ & 1 & $2,32 \%$ \\
\hline 2 & $39-56$ & Kurang & 8 & $18,28 \%$ \\
\hline 3 & $57-74$ & Cukup & 14 & $33,90 \%$ \\
\hline 4 & $75-91$ & Baik & 12 & $26,90 \%$ \\
\hline 5 & $86-100$ & $\begin{array}{l}\text { Sangat } \\
\text { Baik }\end{array}$ & 8 & $18,60 \%$ \\
\hline \multicolumn{3}{|c|}{ Jumlah } & 43 & $100 \%$ \\
\hline \multicolumn{3}{|c|}{$\begin{array}{c}\text { Rata-rata hasil angket minat } \\
\text { baca }\end{array}$} & \multicolumn{2}{|c|}{69,38} \\
\hline \multicolumn{3}{|c|}{$\begin{array}{c}\text { Skor angket minat baca } \\
\text { tertinggi }\end{array}$} & \multicolumn{2}{|c|}{100} \\
\hline \multicolumn{3}{|c|}{$\begin{array}{c}\text { Skor angket minat baca } \\
\text { terendah }\end{array}$} & \multicolumn{2}{|c|}{30} \\
\hline
\end{tabular}

Dari data tabel 4 dapat dilihat bahwa siswa yang masuk kategori sangat kurang dari 1 siswa atau 2,32\%, kategori kurang 8 siswa atau 18,28\%, kategori cukup 14 siswa atau 33,90\%, kategori baik 12 siswa atau 26,90\%, dan kategori sangat baik 8 siswa atau $18,60 \%$. Rata-rata hasil angket siswa 69,38\% dalam kategori cukup 


\section{Deskripsi Pelaksanaan Tindakkan Siklus II}

a. Tahap perencanaan

Perencanaan pembelajaran pada siklus II merupakan hasil tindak lanjut dari kekurangan yang didapat pada siklus I. pada siklus II ini juga terdiri dari 2 pertemuan. Pertemuan pertama berlangsung 2x35 menit dan pertemuan kedua berlangsung 3×35 menit karena evaluasi hasil belajar akan dilaksanakan pada pertemuan kedua. Kompetensi dasar yang dipelajari masih sama, tetapi indicator pembelajarannya berbeda. Sebelum melakukan pembelajaran peneliti yang menjadi guru mempersiapkan hal-hal sebagai berikut:

1) Menyiapkan materi pelajaran yang akan disampaikan.

2) Mempersiapkan alat peraga yang mendukung pembelajaran.

3) Menyiapkan rencana pelaksanaan pembelajaran pada siklus II.

4) Menyiapkan lembar observasi guru dan siswa untuk mengtahui keberhasilan penggunaan metode $S Q 3 R$.

5) Menyiapkan lembar angket minat untuk mengetahui siswa setelah pembelajaran.

6) Menyiapkan lembar kerja siswa dan lembar evaluasi.

\section{b. Tahap Pelaksanaan Pertemuan I}

Pertemuan I dilaksanakan pada hari senin 20 maret 2018. Kompetensi dasar yang digunakan oleh guru masih sama dengan kompetensi dasar pada siklus I. Indikator yang dibahas pada pertemuan kali ini ada 4 indikator.

Pada kegiatan awal, guru mengawali dengan memeriksa kehadiran siswa, kesiapan siswa dan apresepsi, pada kesempatan ini guru menceritakan tentang kegiatan manusia yang mempengaruhi siklus air, kemudian siswa diminta untuk menanggapi cerita yang dibawakan oleh guru. menyampaikan tujuan pembelajaran yang akan dilaksanankan.

Pada kegiatan inti guru meminta siswa membuka buku teks yang telah dipersiapkan guru kemudian meminta siswa untuk membaca dan mengamati teks narasi yang terdapat pada buku tersebut. Setelah siswa membaca buku, siswa diminta menulis hal yang penting. Siswa dinta membuat pertanyaan dan setelah selasesai ditukarkan dengan teman sebangkunya. Siswa diminta untuk menjawab pertanyaan yang mereka sudah dapatkan. Guru bertanya dan menguatkan materi tentang siklus air. Setealah selesai dan siswa paham dengan materi.siswa diminta untuk mengejakan lembar kerja siswa yang ada di buku. Siswa dan guru membahas bersama jawaban lembar kerja siswa.
Pada kegiatan akhir guru bertanya jawab dengan siswa mengenai materi yang belum jelas. Guru memberikan apresiasi kepada siswa yang berani bertanya dan mengungkapkan pendapat. Siswa Bersama guru menyimpulkan materi yang telah dipelajari pada pertemuan kali ini. Guru menutup dengan memberikan motivasi kepada siswa dan mengucapkan salam.

\section{Pertemuan II}

Pada kegiatan awal, guru mengawali dengan memeriksa kehadiran siswa, kesiapan siswa dan apresepsi, pada kesempatan ini guru menceritakan tentang kegiatan manusia yang mempengaruhi siklus air, kemudian siswa diminta untuk menanggapi cerita yang dibawakan oleh guru.

Pada kegiatan inti pembelajaran guru memberi penjelasan kegiatan yang akan dilakukan siswa selama pembelajaran berlangsung, kemudian menyuruh peserta didik membaca buku tema kelas $\mathrm{V}$ tentang daur air dan mencatat atau mengaris bawahi hal yang penting, dilanjut dengan membuat pertanyaan yang kemudian akan ditukar dengan teman dan menjawab dengan membaca buku sains. Kemudian siswa memmbacakan soal yang ia peroleh dan jawabannya, sedangkan guru mengoreksi jika ada kesalahan pada siswa. setelah itu, guru dan siswa bersama-sama menyebutkan pertanyaan yang dibuat siswa dan jawaban yang sudah dikoreksi.

Pada kegiatan penutup pembelajaran, guru mengarahkan siswa untuk mencatat kesimpulan. Kemudian siswa mengerjakan soal evaluasi yang berjumlah 20 soal pilihan ganda. Setelah selesai mengerjakan soal, siswa mengumpulkan jawaban. Guru mengakhiri pembelajaran dan memberikan motivasi untuk lebih giat membaca dan belajar. Guru mengucapkan salam.

\section{c. Hasil Tindakan Hasil Belajar}

Pembelajaran siklus II pada pertemuan pertam dan kedua, serta hasil evaluasi pada pertemuan ke II, diapat dilihat di dalam tabel hasil belajar IPA dibawah ini:

TABEL 5

HASIL BELAJAR IPA SIKLUS II

\begin{tabular}{|c|c|c|c|}
\hline No & Nilai & $\begin{array}{c}\text { Jumlah } \\
\text { siswa }\end{array}$ & $\begin{array}{c}\text { Presentasi } \\
(\%)\end{array}$ \\
\hline 1 & $45-55$ & 2 & 4,65 \\
\hline 2 & $56-65$ & 2 & 4,65 \\
\hline 3 & $66-75$ & 11 & 25,60 \\
\hline 4 & $76-85$ & 13 & 30,25 \\
\hline 5 & $86-100$ & 15 & 34,95 \\
\hline \multicolumn{2}{|c|}{ Jumlah } & 43 & 100 \\
\hline \multicolumn{2}{|c|}{ Rata-rata hasil belajar } & \multicolumn{2}{|c|}{78,5} \\
\hline \multicolumn{2}{|c|}{ Skor tertinggi } & \multicolumn{2}{|c|}{95} \\
\hline \multicolumn{2}{|c|}{ Skor terendah } & \multicolumn{2}{|c|}{45} \\
\hline
\end{tabular}


Berdasarkan tabel 5 dapat dilihat bahwa siswa yang mendapatkan nilai dengan rentang $45-55$ sebanyak 9 siswa ( 20,93\%), siswa yang mendapatkan nilai pada rentang $56-65$ sebanyak 9 siswa ( 20,93\%), siswa yang mendapatkan nilai pada rentang 66 - 75 sebanyak 10 siswa $(23,26 \%)$, siswa yang mendapatkan nilai pada rentang $76-85$ sebanyak 8 siswa $(18,61 \%)$, siswa yang mendapatkan nilai pada rentang 86 - 100 sebanyak 7 siswa $(16,27 \%)$. Nilai rata - rat siswa pada kondisi awal sebelum dilakukan penelitian tindakan kelas yaitu 67,91 Nilai terendah pada kondisi awal adalah 45 dan nilai tertinggi adalah 95 .

\section{a. Minat Belajar Siswa}

Untuk mengukur minat siswa terhadap muatan pelajaran IPA, guru memberikan angket kepada keseluruhan siswa. Angket berisi pernyataan yang dapat menunjukkan tingkat minat seorang siswa pada muatan pelajaran IPA. Angket minat diisi oleh siswa berdasarkan perasaannya sendiri. Dari keseluruhan data angket minat yang terkumpul dapat dilihat hasil analisis skor minat belajar siswa pada tabel 6

TABEL 6

SKOR ANGKA MINAT BELAJAR IPA SIKLUS II

\begin{tabular}{|c|c|c|c|}
\hline Interval & Kategori & Frekuensi & $\begin{array}{c}\text { Presentasi } \\
\text { (\%) }\end{array}$ \\
\hline $21-38$ & $\begin{array}{l}\text { Sangat } \\
\text { Kurang }\end{array}$ & $\mathrm{O}$ & o \\
\hline $39-56$ & Kurang & 5 & $11,62 \%$ \\
\hline $57-74$ & Cukup & 9 & $21 \%$ \\
\hline $75-91$ & Baik & 19 & $44,18 \%$ \\
\hline $92-105$ & $\begin{array}{l}\text { Sangat } \\
\text { Baik }\end{array}$ & 10 & $23,20 \%$ \\
\hline \multicolumn{2}{|c|}{ Jumlah } & 43 & $100 \%$ \\
\hline \multicolumn{3}{|c|}{ Rata-rata hasil angket minat } & $89,75 \%$ \\
\hline \multicolumn{3}{|c|}{ Skor angket minat tertinggi } & 100 \\
\hline \multicolumn{3}{|c|}{ Skor angket minat terendah } & 50 \\
\hline
\end{tabular}

Pada tabel 6 kategori kurang ada 5 siswa atau $11,62 \%$, kategori cukup 9 siswa atau 21\%, kategori baik ada 19 siswa atau $44,18 \%$, dan kategori sangat baik ada 10 siswa atau 23,20\%. Rata-rata meningkat daripada hasil siklus I menjadi 89,75\% dalam kategori baik, skor angket tertinggi 100 dan terendah 50

\section{Pembahasan}

Penelitian tindakan ini memfokuskan pada upaya perbaikan untuk meningkatkan hasil belajar dan minat baca siswa pada mupel IPA kelas V SDN Salatiga 9 dengan menerapkan metode pembelajaran SQ3R. Dengan melaksanakan Langkah-langkah metode pembelajaran SQ3R: siswa diminta untuk membaca bacaan materi dalam buku dan mengarisbawahi yang penting, setelah mengaris bawahi siswa diminta untuk membuat pertanyaan yang kemudian akan ditukar dengan teman, dan menjawab dengan membaca buku sains, kemudian siswa membacakan soal yang ia peroleh dan jawabanya, sedangkan guru mengoreksi jika ada kesalahan pada jawaban siswa. setelah itu guru dan siswa besama- sama menyebutkan kembali pertanyaan yang dibuat siswa dan jawabannya yang sudah dikoreksi. Melalui metode SQ3R siswa dituntut untuk lebih aktif, dan lebih meningkatkan pemahaman membaca.

Dalam penelitian tindakan kelas yang telah dilaksanakan, peneliti meringkas peningkatan hasil belajar dan minat baca siswa kelas V SDN Salatiga 09 pada mupel IPA yang terjadi selama dua siklus. Persentasi hasil belajar pada siklus 1 yakni 67,91\%. Pada siklus II juga terjadi peningkatan hasil belajar siswa menjadi $78,5 \%$. Dan persentasi minat baca siswa pada siklus I yakni $69,38 \%$. Pada siklus ke II terjadi peningkatan menjadi $89,75 \%$.

Penerapan metode Survey, Question, Read, Recite, Review (SQ3R) telah berhasil meningkatkan hasil belajar dan juga minat baca siswa kelas V SDN Salatiga 9, Kecamatan Sidorejo, Kota Salatiga pada mupel IPA semester II tahun ajaran 2017/2018. Hasil penelitian yang menunjukan peningkatan dari pelaksanaan siklus I dan siklus II juga sejalan dengan penelitian yang telah dilakukan Wahyuni, Renti; Hidayat Saleh; Dewiyeti, Susi (2010) yang menyimpulkan bahwa metode pembelajaran SQ3R dapat meningkatkan hasil belajar dan minat baca.

Berdasarkan pembahasan uraian pembahasan tersebut maka dapat dipaparkan implikasi praktis yang terjadi setelah pelaksanaan penelitian tindakan kelas ini yakni guru menemukan alternatif penggunaan metode pembelajran yang inovatif untuk memperbaiki mutu pembelajaran. Selain itu, pengetahuan dan ketrampilan guru berkembang menjadi lebih baik. Guru juga dapat menerapkan tindakan perbaikan pembelajran sebagai upaya meningkatkan profesionalisme kerja.

Bagi siswa, implikasi dari penelitian ini adalah menumbuhkan motivasi dan perhatian siswa untuk belajar, meningkatkan hasil belajar pada mupel IPA, serta membantu siswa membiasakn membaca.

\section{E. SIMPULAN DAN SARAN}

Berdasarkan hasil penelitian yang telah dijelaskan di Bab IV dapat disimpulkan bahwa penelitian yang telah dilaksanakan dari pra siklus, siklus I, sampai siklus II, dengan menggunakan metode SQ3R pada siswa kelas V SDN Salatiga o9 telah meningkatkan hasil belajar dan minta baca siswa pada mupel IPA kompetensi dasar 3.8 yaitu menganalisis terjadinya siklus air dan dampaknya pada peristiwa di bumi serta kelangsungan makhluk hidup.

Berdasarkan hasil penelitian yang membutikan bahwa penggunaan metode pembalajaran SQ3 R dapat meningkatkan hasil belajar dan minat baca siswa, maka peneliti memberikan saran kepada: 
1. Bagi guru kelas. Diharapkan guru dapat meningkatkan minat baca siswa melalui metode SQ3R.

2. Bagi Siswa. Diharapkan siswa SDN Salatiga 9 Kecamatan Sidorejo, Kota Salatiga diharapkan dapat meningkatkan minat baca yang sudah dimiliki, terutama minat baca pada buku-buku pelajaran IPA dan buku-buku pelajaran yang lainnya untuk mencapai hasil belajar yang baik.

3. Bagi Sekolah. Diharapkan ada kerjasama antara kepala sekolah, guru, maupun perpustakaan sekolah dalam membimbing siswa untuk meningkatkan minat baca serta lebih mengoptimalkan fungsi baik dari segi pelayanan maupun perawatan bahan perpustakaan.

4. Bagi Peniliti Selanjutnya. Diharapkan peniliti selanjutnya mampu melakukan penelitian dalam upaya peningkatan hasil belajar siswa dengan memperhatikan banyak variabel, baik variabel yang bersumber dalam diri siswa maupun yang bersumber dari luar diri siswa yang berhubungan dengan hasil belajar siswa.

\section{UCAPAN TERIMA KASIH}

Penulis mengucapkan terima kasih kepada Allah SWT yang telah memberikan nikmat yang didapat digantikan dengan apapun. Kepada semua pihak yang telah membantu dalam proses penelitian. Terutama kepada orang tua yang selalu memberikan dorongan berupa semangat dan doa, kepada dosen pembimbing dan juga teman - teman. Terima kasih kepada SD N Salatiga 9 yang telah memberikan kesempatan untuk melakukan penelitian.

\section{DAFTAR RUJUKAN}

[1] Agus S, 2003, Pengertian Ilmu Pengetahuan Alam, tersediadihttp://id.wikipedia.org/wiki/Ilmu_Pengetahu an_Alam.html[Desember,2012

[2] Al-Hafizh, Mushlihin (2012). [Online]. Tersedia: http://www.referensimakalah.com/2012/11/modelpembelajara-SQ3R.html [7 maret 2013]

[3] Arikunto. (2012). Dasar-dasar evaluasi pendidikan. jakarta.

[4] Dyahpuspita, N. (2015). Pengaruh Metode $S Q 3 R$ Terhadap Kemampuan Membaca Pemahaman . yogyakarta: Universitas Negeri Yogyakarta.

[5] Fitria.2011. Kelebihan-dan-kelemahan-metode $S Q 3 R$. tersediapadahttp://www.fitria507.blogspot.com/2011/1 2/kelebihan-dan-kekurangan metode.html Jumat, o9 Desember 2011

[6] Herdian. (2009). Model SQ3R.[tersedia online]: model pembelajaran SQ3R $<<$ Herdian, S. Pd. Htm [25 Januari 2010]

[7] Miftahul Huda, M. (2013). model-model pengajaran dan pembelajaran. yogyakarta: PUSTAKA PELAJAR (Arikunto, 2012)

[8] Mulyasa. (2013). Pengembangan dan Implementasi Kurikulum 2013. Bandung.

[9] Poerwanti, Endang. Dkk. 2008. Assesmen PembelajaranSD.Dirjen Dikti Depdiknas. Jakarta.
[10] Rahim, (2011) Pengajaran Membaca di Sekolah Dasar, Jakarta: Bumi Aksara

[11] Ratnasari, Yunita. (2011).Pengaruh Pergaulan Teman Sebaya Terhadap Minat Baca Siswa Kelas V SD Negeri Bojongsari I Kabupaten Purbalingga. Skripsi Sarjana pada FIP UNY Yogyakarta.

[12] Rachman, abd. dkk. 1985. Minat Baca Murid SD Di Jawa Timur. Jakarta : Pusat Pembinaan dan Pengembangan Bahasa Depdikbud.

[13] Sudjana, Nana, (2009) yPenilain Hasil Proses Belajar Mengajar,Bandung: Remaja Rosdakarya.

[14] Trianto.(2010).ModelPembelajaranTerpadu.Jakarta:Bu mi Araksa

\section{PROFIL PENULIS UTAMA}

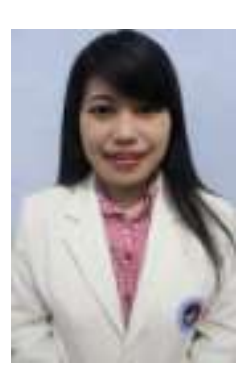

Penulis bernama lengkap Sri Ambarwati, lahir di Kab. Semarang o8 oktober 1996. Penulis tinggal di Desa Sepakung Kecamatan Banyubiru Kabupaten Semarang . Penulis memulai pendidikan pertamanya di Sd N Sepakung 01 pada tahun 2002 - 2008, kemudian di Smp Islam Sudirman Banyubiru pada tahun 2008 - 2011, kemudian melanjutkan di Smk Masehi Ambarawa pada Tahun 2011 - 2014 kemudian masuk pada jenjang perguruan tinggi di Unuversitas Kristen Satya Wacana pada tahun 2014. Segala kritik dan saran yang membangun bisa dikirim ke email penulis di : 292014013@student.uksw.edu 